\title{
Effect of ionized water and stratification on the condition of Allium ursinum L. seeds
}

\section{Regina Malinauskaitè,}

\section{Aurelija Šaluchait $\dot{e}^{\star}$}

Institute of Biology and Plant Biotechnology,

Aleksandras Stulginskis University,

11 Studentu St., Akademija 53361,

Kaunas district, Lithuania

\begin{abstract}
One of the rarer problems that occur in growing medicinal and spice plants is ensuring the quality of the propagating material. Germination of seeds of one of these plants, Allium ursinum L., is slow. To improve that, stratification is used. In the experiment, which was carried out in Lithuania in 2016, evaluation of fourand five-week long stratification and the use of alkaline ionized ( $\mathrm{pH}$ 8.6) water for germination affect for Allium ursinum L. seeds were evaluated. It was found that the above-mentioned intervals for stratification did not affect the beginning of seed germination. Furthermore, one of the possible reasons for slower germination was found, and it was the incidence of seed diseases caused by fungi and bacteria. Allium ursinum L. seeds were affected the most by Penicillium ssp. micromycetes. The longer the period of stratification, the more alkaline ionized water decreased the effect of Mucor ssp. micromycetes.
\end{abstract}

Keywords: wild garlic, alkaline ionized water, germination, seed diseases

\section{INTRODUCTION}

The importance of Allium ursinum L. as a spice has risen in the last decades, however, its chemical consistency depends on the growing conditions (Sobolewska et al., 2011).

Allium ursinum L. is a typical representative of its genus and has been used for centuries in traditional medicine. Allium ursinum is a perennial herbaceous plant, of wide-spread distribution both in Europe and Asia. Although it does not grow at high altitudes (beyond $1.900 \mathrm{~m}$ ) and in the far North (beyond ca. $64^{\circ} \mathrm{N}$ ), it can be found in natural stands from the Mediterranean region to Scandinavia (Oborny et al., 2011). It is also native to Asia Minor, the Caucasus, and Siberia (Madaus, 1938; Djurdjevic et al., 2004; Oborny et al., 2011; Rola, 2012).

\footnotetext{
* Corresponding author. Email: aurelija.saluchaite@asu.lt
}

Two subspecies of $A$. ursinum are recognized: A. ursinum ssp. ursinum and $A$. ursinum ssp. ucrainicum. The subdivision is based on the smoothness of the pedicel surface (Karpavičienè, 2006). The pedicels of the ssp. ursinum are scabrid, with numerous papillae, and rough, while the ssp. ucrainicum has smooth pedicels without papillae (Farkas et al., 2012; Rola, 2012). The former is distributed in western and central Europe, whereas the latter in the eastern and south-eastern part of the continent (Oborny et al., 2011; Rola, 2012). The distribution areas of the two subspecies can overlap what results in the existence of transitional forms. In Poland, both subspecies, along with the intermediate forms occurring at the border of the distribution ranges, were recorded (Rola, 2012).

A. ursinum is considered one of the species the patchy distribution of which is a characteristic feature of the herb layer in the Hordelymo-Fagetum forest community. Under the dense carpets 
of these species, competition for space and light is likely to occur (Leuschner, Lendzion, 2009). A. ursinum is a strong inter-specific competitor, which affects the growth of other herbaceous plants via soil where phenolic phytotoxins (produced by ramson) are accumulated (Djurdjevic et al., 2004).

Allium ursinum L. is most commonly multiplied by seeds. Most of the seeds can stay in the state of rest from one to two years (Eggert, 1992). The majority of the population (50-70\%) consist of sprouts and young plants. Flowering individuals make up 3-5\%. In Lithuania, large overgrowth of species is found in the districts of Biržai, Taurage, Kedainiai, and Kretinga. It is very rare in the southern and eastern parts of Lithuania (Karpavičienė, 2004; Karpavičienè, 2007). Human economic activity has the greatest negative influence on the prevalence and abundance of Allium plants. In order to satisfy the needs of the market and to protect populations, attempts are made to cultivate Allium since plants cannot be harvested in natural plant sites. However, the quality of the adapted propagating material is questionable.

The plants of this genus may suffer from parasitic micromycetes, which under favourable conditions can significantly reduce the seed yield (Karpavičiené, 2004). Meteorological conditions are of great importance in the spread of diseases. Under low air temperature and high relative humidity, the plants are damaged by blights - Botrytis and Fusarium genus fungus, particularly in spring when Allium plants are frozen. Micromycetes spread easier by seeds and bulbs. Twenty-two species of 28 micromycetes are found on the seeds of these plants. Mostly, the saprotrophic Hyphomycetes fungi were found (Survilienè et al., 2005).

Grigaliūnaitè and Karpavičienè (2004) found that saprotrophic micromycetes were most commonly found on the leaves of dried Allium plants. Most micromycetes are found on seeds and bulbs, although some literature sources (Synoviec et al., 2010) maintain that plant-produced compounds can suppress the activity of some micromycetes, including Aspergillus niger, Penicillium expansum.
The main aim of this experiment was to evaluate germination of Allium ursinum seeds stratified for four and five weeks, and its reducing factors.

\section{MATERIALS AND METHODS}

To evaluate the influence of four and five weeks of stratification and alkaline ionized water $(\mathrm{pH} 8.6)$ on the germination and condition of seeds of Allium ursinum L., the seeds were put in ignited sand and cooled down for four ( 28 days) and five weeks (35 days) in $5-6^{\circ} \mathrm{C}$ temperature. Each Petri dish had 25 seeds. The sand for the control variant was moistened with distilled water, while the experimental one was moistened with alkaline ionized water, which was made with ionizer PTV-KL. After the required period of time in stratification, the Petri dishes were taken into the oven with natural air convection Ecocell MMM with $22 \pm 24^{\circ} \mathrm{C}$ temperature inside. Each variant of the experiment was repeated three times. Germination and condition of seeds were determined after three, six, and 12 days. Seeds from UAB "Nojaus sèklos" were used in this experiment.

To evaluate the condition of seeds, disease incidence was calculated using the formula from Šurkus and Gaurilčikienè (2002):

$$
P=n / N \times 100,
$$

when $P$ - incidents of disease, $\% ; n$ - number of disease incidents on seeds, units, $N$ - number of examined seeds, units.

The genus of prevailing fungi diseases was identified (Dugan, Frank M., 2006).

Statistical data was analysed with one-way ANOVA method using STATISTICA software package.

\section{RESULTS AND DISCUSSION}

Literature notes (Eggert, 1992) that in the state of rest seeds can exist for one to two years, however, germination can begin before winter or in spring. That is how seeds went through the state of rest or the period of stratification. In this experiment, stratification of 4-5 weeks in the spring after the state of rest was conducted. 
However, despite the length of stratification or water germination, the seeds did not germinate after the recommended 12-day period (Table 1). During the monitoring, one of the possible reasons for this situation was found and it was diseases on the seeds. Literature suggests that Allium ursinum can produce secondary metabolites, which inhibit growth and germination of other plants (Djurdjevic et al., 2004), and growth of some bacteria (Staphylococcus aureus, Bacillus subtilis, Escherichia coli, Proteus mirabilis, Salmonella enteritidis) and micromycetes (Aspergillus niger, Rhizopus nigricans, Geotrichum candidum, Penicillium expansum, Candida lipolytica, Mycoderma, Saccharomycopsis fibuligera) (Synowiec et al., 2010) growth.

In this experiment, disease incidence on seeds in the control variant after four weeks of stratification increased from $16 \%$ to $33.3 \%$, or 2.08 times in the period from day 3 to day 12 of monitoring. In the analogical variant, but with alkaline ionized water, seed disease incidence on the seeds increased from $14.0 \%$ to $26.0 \%$, or 1.85 times. Compared with the control, alkaline ionized water decreased disease incidence statistically significantly, 1.28 times. Comparing five-week stratification with a shorter period of time, common disease incidence was lower in the control and in the alkaline ionized water variant. In the control variant, it increased from $2.7 \%$ to $24.0 \%$, or 8.88 times, and in the alkaline ionized water variant from $4 \%$ to $10 \%$, or 2.5 times, through the entire time of monitoring. Compared with the control, differences are sig- nificant. Results show that a longer period of stratification resulted in a lower disease incidence on seeds.

Lithuanian scientists (Zitikaitè et al., 2011) suggest that Allium ursinum L. and especially its seeds and fruits can be mostly affected by rots. The reason for that can be micromycetes, which contaminate racemes when the latter droop down after the blossoming and touch soil. In this experiment bacteria and especially micromycetes caused diseases (Table 2). Symptoms of fungi diseases in control seeds were developing gradually, independently of the length of stratification. In the alkaline ionized water variant, the symptoms were found at the beginning of germination.

Disease incidences (in micromycetes) on seeds after four weeks of stratification increased 1.9 times in the control variant and 1.57 times in the alkaline ionized water variant. After five weeks of stratification, incidences of disease with micromycetes at the end of germination were as many as 7.4 times higher in the control, while in the alkaline ionized water variant only $6.0 \%$ of micromycetes-affected seeds were found.

According to Lithuanian scientists (Karpavičienè, 2004; Survilienè et al., 2005), saprotrophic micromycetes are most commonly found on dried leaves of Allium plants, and mainly on seeds and bulbs. In our experiment, when the propagating material from the supplier UAB "Nojaus sèklos" was used, in all cases the incidences of diseases of Allium ursinum were caused by Penicillium ssp. (Table 3).

Table 1 . Influence of stratification duration and ionized alkaline water on the germination and condition of Allium ursinum L. seeds

\begin{tabular}{|c|c|c|c|c|c|c|c|}
\hline \multirow{3}{*}{$\begin{array}{l}\text { Length of strati- } \\
\text { fication, weeks }\end{array}$} & \multirow{3}{*}{$\begin{array}{l}\text { Variants of } \\
\text { treatment }\end{array}$} & \multicolumn{6}{|c|}{ Periods of monitoring from the beginning of germination, days } \\
\hline & & \multicolumn{2}{|c|}{3 days } & \multicolumn{2}{|c|}{6 days } & \multicolumn{2}{|c|}{12 days } \\
\hline & & $\begin{array}{c}\text { Germina- } \\
\text { tion, } \%\end{array}$ & $\begin{array}{l}\text { Disease in- } \\
\text { cidence, \% }\end{array}$ & $\begin{array}{c}\text { Germina- } \\
\text { tion, } \%\end{array}$ & $\begin{array}{c}\text { Disease inci- } \\
\text { dence, } \%\end{array}$ & $\begin{array}{c}\text { Germina- } \\
\text { tion, \% }\end{array}$ & $\begin{array}{c}\text { Disease inci- } \\
\text { dence, } \%\end{array}$ \\
\hline \multirow{2}{*}{4} & Control & 0 & $16.0 \pm 3.1$ & 0 & $20.0 \pm 2.0$ & 0 & $33.3 \pm 2.7$ \\
\hline & IAW pH 8.6 & 0 & $14.0 \pm 2.3$ & 0 & $18.0 \pm 1.5$ & 0 & $26.0 \pm 3.1^{*}$ \\
\hline \multirow{2}{*}{5} & Control & 0 & $2.7 \pm 0.5$ & 0 & $14.7 \pm 1.5$ & 0 & $24.0 \pm 1.2$ \\
\hline & IAW pH 8.6 & 0 & $4.0 \pm 0.0^{*}$ & 0 & $8.0 \pm 0.0^{*}$ & 0 & $10.0 \pm 0.5^{*}$ \\
\hline
\end{tabular}

Note: ${ }^{*}$ essential differences compared with the control, confidence level of $P<0.05$; control - distilled water, IAW - ionized alkaline water. 
Table 2. Disease incidence on Allium ursinum L. seeds

\begin{tabular}{|c|c|c|c|c|c|c|c|}
\hline \multirow{3}{*}{$\begin{array}{l}\text { The length of } \\
\text { stratification, } \\
\text { weeks }\end{array}$} & \multirow{3}{*}{$\begin{array}{l}\text { Variants of } \\
\text { treatments }\end{array}$} & \multicolumn{6}{|c|}{ Periods of monitoring from the beginning of germination, days } \\
\hline & & \multicolumn{2}{|c|}{3 days } & \multicolumn{2}{|c|}{6 days } & \multicolumn{2}{|c|}{12 days } \\
\hline & & $\begin{array}{c}\text { Fungous } \\
\text { diseases, \% }\end{array}$ & $\begin{array}{c}\text { Bacterial } \\
\text { diseases, \% }\end{array}$ & $\begin{array}{c}\text { Fungous } \\
\text { diseases, \% }\end{array}$ & $\begin{array}{c}\text { Bacterial } \\
\text { diseases, \% }\end{array}$ & $\begin{array}{c}\text { Fungous } \\
\text { diseases, \% }\end{array}$ & $\begin{array}{c}\text { Bacterial } \\
\text { diseases, \% }\end{array}$ \\
\hline \multirow{2}{*}{4} & Control & $14.7 \pm 2.3$ & $1.3 \pm 0.6$ & $16.0 \pm 2.0$ & $4.0 \pm 0.0$ & $28.0 \pm 0.0$ & $5.3 \pm 2.7$ \\
\hline & IAW pH 8.6 & $14.0 \pm 2.3$ & $0.0 \pm 0.0^{*}$ & $14.0 \pm 1.5$ & $4.0 \pm 0.0$ & $22.0 \pm 1.2^{*}$ & $4.0 \pm 0.0$ \\
\hline \multirow{2}{*}{5} & Control & $2.7 \pm 0.5$ & $0.0 \pm 0.0$ & $12.0 \pm 1.2$ & $2.7 \pm 0.5$ & $20.0 \pm 1.0$ & $4.0 \pm 0.5$ \\
\hline & IAW pH 8.6 & $0.0 \pm 0.0^{*}$ & $4.0 \pm 0.0$ & $4.0 \pm 0.0^{*}$ & $4.0 \pm 0.0$ & $6.0 \pm 0.5$ & $4.0 \pm 0.0$ \\
\hline
\end{tabular}

Note: ${ }^{\star}$ essential differences compared with control, confidence level of $P<0.05$; control - distilled water, IAW - ionized alkaline water.

Table 3. Incidences of fungal disease on Allium ursinum L. seeds

\begin{tabular}{|c|c|c|c|c|c|}
\hline \multirow{2}{*}{$\begin{array}{c}\text { Length of } \\
\text { stratification, } \\
\text { weeks }\end{array}$} & \multirow{2}{*}{$\begin{array}{l}\text { Periods of monitoring } \\
\text { from the beginning of } \\
\text { germination, days }\end{array}$} & \multirow{2}{*}{$\begin{array}{l}\text { Variants of } \\
\text { treatment }\end{array}$} & \multicolumn{3}{|c|}{ Micromycetes, \% } \\
\hline & & & Fusarium ssp. & Mucor ssp. & Penicillium ssp. \\
\hline \multirow{4}{*}{4} & \multirow{2}{*}{6} & control & $4.0 \pm 0.4$ & $4.0 \pm 0.6$ & $8.0 \pm 0.9$ \\
\hline & & IAW pH 8.6 & - & $2.0 \pm 0.5$ & $12.0 \pm 1.0$ \\
\hline & \multirow{2}{*}{12} & control & $4.0 \pm 0.0$ & $8.0 \pm 0.0$ & $16.0 \pm 0.0$ \\
\hline & & IAW pH 8.6 & $3.0 \pm 0.5$ & $2.0 \pm 0.3$ & $16.0 \pm 0.7$ \\
\hline \multirow{4}{*}{5} & \multirow{2}{*}{6} & control & - & $2.6 \pm 0.5$ & $9.3 \pm 0.7$ \\
\hline & & IAW pH 8.6 & $4.0 \pm 0.0$ & - & - \\
\hline & \multirow{2}{*}{12} & control & $4.0 \pm 0.2$ & $4.0 \pm 0.1$ & $12.0 \pm 0.7$ \\
\hline & & IAW pH 8.6 & $4.0 \pm 0.2$ & - & $2.0 \pm 0.2$ \\
\hline
\end{tabular}

Note: control - distilled water, IAW - ionized alkaline $\mathrm{pH} 8.6$ water.

These micromycetes accounted for $16.0 \%$, or $48.0 \%$ of the total disease incidence in the control variant after four weeks of stratification. Disease incidence in the alkaline ionized water variant reached $16.0 \%$, or as much as $61.0 \%$ of the total disease incidence. After five weeks of stratification, the incidence of diseases caused by the micromycetes in the control variant and in the alkaline ionized water variant, reached $16.0 \%$ or half of the total disease incidence, and $2.0 \%$, or $20.0 \%$ of the overall disease incidence, respectively. Conditions like temperature (higher than $22^{\circ} \mathrm{C}$ ) and sufficient humidity most likely were favourable for micromycetes during the germination.

Very likely the length of stratification with alkaline ionized water became an environment unfavourable not only for that genus of micromycetes but also for Mucor ssp., which were not found in seeds of this variant.

\section{CONCLUSIONS}

Green mass of Allium ursinum is in demand in pharmacy and food industry because of its biochemical composition. However, in Lithuania it is allowed to gather seeds only from natural plant sites, which can be infected by various pathogens just like those acquired from centralized suppliers. Allium ursinum seeds usually remain in the state of rest for a long time. This situation was proven by current experiment, which showed that four or five weeks of stratification were not enough for the interruption of the state of rest. Some of the seeds died during germination because of diseases caused by micromycetes and bacteria. In our case, a longer period of stratification lowered the overall disease incidences on seeds, especially when alkaline ionized water was used. It can be stated that 
an alkaline environment was less favourable for micromycetes, particularly for Mucor ssp., than distilled water. Of all the micromycetes, Penicillium ssp. caused the highest incidence of seed diseases, especially when distilled water was used for germination.

Received 9 April 2018

Accepted 30 May 2018

\section{References}

1. Błażewicz-Woźniak M, Michowska A. The growth, flowering and chemical composition of leaves of three ecotypes of Allium ursinum L. Acta Agrobot. 2011; 64(4): 171-180. https://doi: 10.5586/aa.2011.058.

2. Djurdjevic L, Dinic A, Pavlovic P, Mitrovic M, Karadzic B, Tesevic V. Allelopathic potential of Allium ursinum L. Biochem Syst Ecol. 2004; 32: 533-44. https://doi: 10.1016/j. bse.2003.10.001.

3. Dugan FM. The identification of fungi: an illustrated introduction with keys, glossary, and guide to literature. USA: The American Phytopathological Society. 2006. 176 p.

4. Eggert A. Dry matter economy and reproduction of a temperate forest spring geophyte Allium ursinum. Ecography. 1992; 15: 45-52.

5. Farkas A, Molnàr R, Morschhauser T, Hahn I. Variation in nectar volume and sugar concentration of Allium ursinum L. ssp. ucrainicum in three habitats. The Scientific World Journal. 2012; 12: 7. http://dx. doi: $10.1100 / 2012 / 138579$.

6. Karpavičienè B. Allium genties rūšių paplitimas Lietuvoje [Distribution of the genus $A l$ lium in Lithuania]. Botanica Lithuanica. Suppl.6; January 2004:19-30. Lithuanian.

7. Karpavičienė B. Distribution of Allium ursinum L. in Lithuania. Acta Biologica Universitatis Daugavpiliensis. 2006; 6: 117-22.

8. Karpavičienè B. In: Rašomavičius V, editor. Lietuvos Raudonoji knyga. Kaunas: Lututè. 2007. p. 548. Lithuanian, summaries in English.
9. Leuschner C, Lendzion J. Air humidity, soil moisture and soil chemistry as determinants of the herb layer composition in European beech forests. J Veg Sci. 2009; 20: 288-98. http://doi: 10.1111/j.1654-1103.2009.05641.x.

10. Oborny B, Botta-Dukat Z, Rudolf K, Morschhauser T. Population ecology of Allium ursinum, a space-monopolizing clonal plant. Acta Bot Hung. 2011; 53(3-4): 371-88. http://doi: 10.1556/ABot.53.2011.3-4.18.

11. Rola K. Taxonomy and distribution of $A l$ lium ursinum (Liliaceae) in Poland and adjacent countries. Biologia. 2012; 67(6): 1080-7. http://doi: 10.2478/s11756-012-0101-2.

12. Synowiec A, Gniewosz M, Zieja I, Baczek K, Przybyl I. Porównanie właściwości przeciwdrobnoustrojowych ekstraktów z czosnku niedźwiedziego (Allium ursinum). Zeszyt Problemowe Postępów Nauk Rolniczych. 2010; 553: 203-209. Available from: http:// yadda.icm.edu.pl/yadda/element/bwmeta1. element.dl-catalog-b2c250fd-2bcc-469f-960f-853b1809050d [cited 2015 Oct 05].

13. Sobolewska D, Galanty A, Michalik M. Preliminary evaluation of cytotoxic activity of Allium ursinum extracts. Czas Aptek. 2012; 12(228): 41-4. Available from: https://sites.google.com/ site/kruidwis/planten-van-a-tot-z/allium-ursinum-daslook [cited 2016 Aug 11].

14. Survilienè E, Raudonis L, Bobinas Č. Beicu poveikio Svalia F1 morkų ir Lietuvos didieji svogūnų sèklų daigumui tyrimai [Effect of seeds treatments on germination of carrots Svalia F1 and onions Lietuvos didieji]. Sodininkystè ir daržininkystè. 2005; 24(2): 73-3. Lithuanian.

15. Zitikaitė I, Karpavičienė B, Urbanavičienè L. Meškinio česnako (Allium ursinum L.) virusinès infekcijos sukèlejai [The agents of virus infection of ramson garlic (Allium ursinum L.)]. Kaunas: Vytauto Didžiojo universiteto leidykla; 2011. p. 13-144. Available from: https://www. researchgate.net/publication/291832767 [2015 Oct 05]

16. Žemès ūkio augalų kenkèjai, ligos ir jų apskaita. Lietuvos žemdirbystès institutas; 2002. p. 12-15. Lithuanian. 
Regina Malinauskaitė, Aurelija Šaluchaitè

JONIZUOTO VANDENS IR STRATIFIKACIJOS POVEIKIS DAIGINAMŲ MEŠKINIO ČESNAKO SĖKLŲ BŪKLEI

\section{Santrauka}

Viena iš retesnių vaistinių ir prieskoninių augalų auginimo problemų - dauginamosios medžiagos kokybès užtikrinimas. Vieno iš jų - meškinio česnako - sèklos dygsta ilgai. Dygimui pagreitinti naudojama stratifikacija. Eksperimento metu buvo ìvertintas 4 ir 5 savaičių stratifikavimo trukmès bei daiginimui panaudoto jonizuoto šarminio $(\mathrm{pH} \mathrm{8,6)}$ vandens poveikis meškinio česnako sèklų daigumui ir jų būklei. Nustatyta, kad minèta stratifikavimo trukmè nenutraukè ramybès laikotarpio ir sèklos nesudygo. Viena iš galimų jų daigumą slopinančių priežasčių - sèklų ligotumas (vyraujančios grybinès ir bakterinès ligos). Keturias savaites stratifikuotuc sèklų pažeidimas mikromicetais iki 12-os daiginimo paros kontrolinejje grupeje (naudotas distiliuotas vanduo) padidèjo 1,9 karto, o naudojant jonizuotą vandeni - 1,57 karto. Penkias savaites stratifikuotų kontrolinès grupès sèklų pažeidimas mikromicetais daiginimo pabaigoje buvo padidejęs 7,4 karto, o dèl jonizuoto vandens poveikio buvo nustatyta $6 \%$ grybinèmis ligomis pažeistų sèklų. Tačiau ilgejjant stratifikavimo trukmei, tiek kontrolinèje grupejje, tiek panaudojus jonizuotą šarminị vandenị bendras sèklų ligotumas mažèjo. Meškinio česnako sèklos labiausiai buvo pažeistos Penicillium ssp. mikromicetais. Jonizuotas šarminis vanduo, ypač pailginus stratifikaciją, slopino Mucor ssp. mikromicetų veiklą.

Raktažodžiai: Allium ursinum, šarminis jonizuotas vanduo, daigumas, sèklų ligotumas 